\title{
A new plate-like hypercalcified chaetetid demosponge (Loiscupula bachendensi gen. nov. sp. nov) from the Cantabrian Zone (Moscovian, Pennsylvanian, NW Spain)
}

\author{
Diego Corrochano and Ronald R. West
}

\begin{abstract}
A new hypercalcified chaetetid sponge, Loiscupula bachendensi gen. nov. sp. nov. (Demospongiae), has been recovered from the Bachende Formation (late Kashirian/early Myachkovian) in the Cantabrian Zone, NW Spain. Loiscupula has a circular, concentric, platy basal skeleton, some with cylindrical features and chimneys, which sometimes branch on the upper surface. The basal skeleton is composed of polygonal (commonly hexagonal) to rounded tubules perpendicular to the surface of the skeleton producing the characteristic honeycomb pattern of chaetetids. Cathodoluminescence microscopy revealed non-luminescent calcite pseudomorphs of monoaxon and polyaxon spicules, rarely styles, which are irregularly distributed although there are occurrences that suggest that a spicular network existed. The basal skeleton is composed of neomorphic low-Mg calcite $\left(1.7 \mathrm{~mol}^{\circ} \mathrm{MgCO}_{3}\right)$ and is strongly recrystallized; the tentative penicillate microstructure with relics of aragonite needles, and the high $\mathrm{Sr}$ content (up to $3456 \mathrm{ppm}$ ), suggest an original aragonite composition. Loiscupula is interpreted as primarily a gregarious organism with an inferred central point of attachment. This mode of growth produced small cryptic cavities between Loiscupula and the substrate, which were inhabited by encrusting organisms, mostly fistuliporid bryozoans. Based on the associated fossils and sedimentological features, it is suggested that Loiscupula inhabited an environment with a muddy bottom in the euphotic zone, where the water was well-oxygenated, of normal salinity, and the energy regime low to moderate.
\end{abstract}

Diego Corrochano. Facultad de Ciencias, Departamento de Geología, Universidad de Salamanca, Plaza de los Caídos s/n, 37008, Salamanca, Spain.dcf@usal.es

Ronald R. West. 1014 Houston Street, Manhattan, Kansas, 66502, USA. rrwest@ksu.edu

Keywords: new genus; chaetetid hypercalcified demosponges; phylloid algae; Pennsylvanian; Cantabrian Zone; Spain

PE Article Number: 16.2.18A

Copyright: Palaeontological Association August 2013

Submission: 14 September 2012. Acceptance: 26 July 2013

Corrochano, Diego and West, Ronald R. 2013. A new plate-like hypercalcified chaetetid demosponge (Loiscupula bachendensi gen. nov. sp. nov) from the Cantabrian Zone (Moscovian, Pennsylvanian, NW Spain), Palaeontologia Electronica Vol. 16, Issue 2; 18A; $18 \mathrm{p}$;

palaeo-electronica.org/content/2013/493-demosponge-from-spain 


\section{INTRODUCTION}

A new chaetetid hypercalcified demosponge, Loiscupula bachendensi gen. nov. sp. nov., occurs in the Bachende Formation (late Kashirian/early Myachkovian, Moscovian, Pennsylvanian), in the Cantabrian Zone, León, NW Spain. Purely on the basis of its external appearance and the strong recrystallization of the skeleton, Loiscupula was previously described as a problematic phylloid alga (Corrochano, 2010), based on a number of similarities with the Rhodophyta and the Chlorophyta, although with certain features found in chaetetids and solenoporaceans. More recent investigation, using cathodoluminescence microscopy, revealed calcite spicule pseudomorphs, and thus they are confirmed chaetetid sponges.

Although forms identified as chaetetid sponges have been reported from rocks as old as the Cambrian (West, 2012a), valid chaetetid genera range from, questionably the Silurian (West, 2012a) to the Recent (Hartman and Goreau, 1972). Chaetetids were common reef-mound builders worldwide during the Early and Middle Pennsylvanian (West, 1988, 2012b; Wahlman, 2002). Palaeozoic chaetetids share morphological features with many groups, including extant calcified demosponges, tabulate corals, stromatoporoids, hydrozoans, trepostome bryozoans and calcareous algae, and they have had a long and complex taxonomic history (for a review see Connolly et al., 1989; West, 2011a). Documentation of spicules and soft tissue typical of demosponges in Acanthochaetetes wellsi by Hartman and Goreau (1972) resulted in the recognition of chaetetids as hypercalcified demosponges. The recognition of fossil chaetetids as hypercalcified demosponges is supported by documentation, in fossil forms, of astrorhizae (Cuif et al., 1973; West and Clark, 1983), and spicule pseudomorphs (Kazmierczak, 1979; Gray, 1980; Reitner and Engeser, 1987; Wood and Reitner, 1988; Cremer, 1995; among others).

This study documents, illustrates and discusses a new genus and species of chaetetid sponge, with comments on its general morphology, preservation, diagenesis, growth habit, associated biota and palaeoecology.

\section{COLLECTIONS AND METHODS}

Twenty-eight Loiscupula specimens were collected in León (NW Spain), from the Bachende Formation, Lois-Ciguera sector, Cantabrian Zone (Figure 1). The collection (USAL LB) is deposited in the Department of Geology at the University of Salamanca, Spain.

Fifteen thin sections were made and examined petrographically with both polarized and transmitted light, and measurements were made at a magnification of $\times 25$. Two thin sections were selected and polished for study using cathodoluminescence $(\mathrm{CL})$ microscopy. A cold $\mathrm{CL}$ unit, model CCL 8200 mklll, with a vacuum chamber coupled to an optical microscope (Nikon Labophot 2-Pol) was employed, working under standard analytical conditions of 12 to $20 \mathrm{kV}$ accelerating voltage, 200 to $400 \mathrm{~mA}$ beam current and vacuum of 0.2 to 0.1 torr. Three fragments of apparently well-preserved specimens were coated with gold and examined with a scanning electron microscope (SEM), model ZEISS DSM 940, following the method proposed by Reitner and Engeser (1987). One polished SEM sample was etched with a weak acid, $5 \%$ titriplexIII-solution $\left(\mathrm{C}_{10} \mathrm{H}_{14} \mathrm{~N}_{2} \mathrm{O}_{18}{ }^{*} 2 \mathrm{H}_{2} \mathrm{O}\right)$; the other two SEM samples examined were freshly fractured surfaces of the calcite skeleton. Trace element analysis $(\mathrm{Mg}, \mathrm{Mn}, \mathrm{Sr}, \mathrm{Fe})$ were determined from bulk samples of five specimens after dissolving the carbonate in $\mathrm{HNO}_{3}$ and $\mathrm{HF}$; samples (0.2-0.5 g) were collected using a high speed dental drill with magnification from a binocular microscope. They were analyzed using an inductively coupled plasma mass spectrometer (ICP-MS), model Perkin-Elmer ELAN 6000 , with an analytical uncertainty of $2 \%$ and a standard calibration. To study the internal structure of the skeleton and its contact with the internal filling matrix, a few specimens were etched by complete immersion in $10 \%$ hydrochloric acid for 10,30 and 60 seconds, respectively. Numerous specimens and a series of evenly spaced sections through a single specimen (USAL LB5) were used to construct an idealized three-dimensional image of Loiscupula.

\section{GEOLOGICAL AND SEDIMENTOLOGICAL SETTING}

The Cantabrian Zone is the external part of the Variscan Orogen in the NW Iberian Peninsula and constitutes the core of the Ibero-Armorican Arc. This area exhibits features characteristic of foreland fold-and-thrust belts, with a thin-skinned deformation and weak metamorphism (PérezEstaún et al., 1988). At least, during the Bashkirian-Moscovian, the Cantabrian Zone represented a wide marine foreland basin with a pronounced asymmetric profile that was in an equatorial position on the eastern coast of Pangea 
(1)
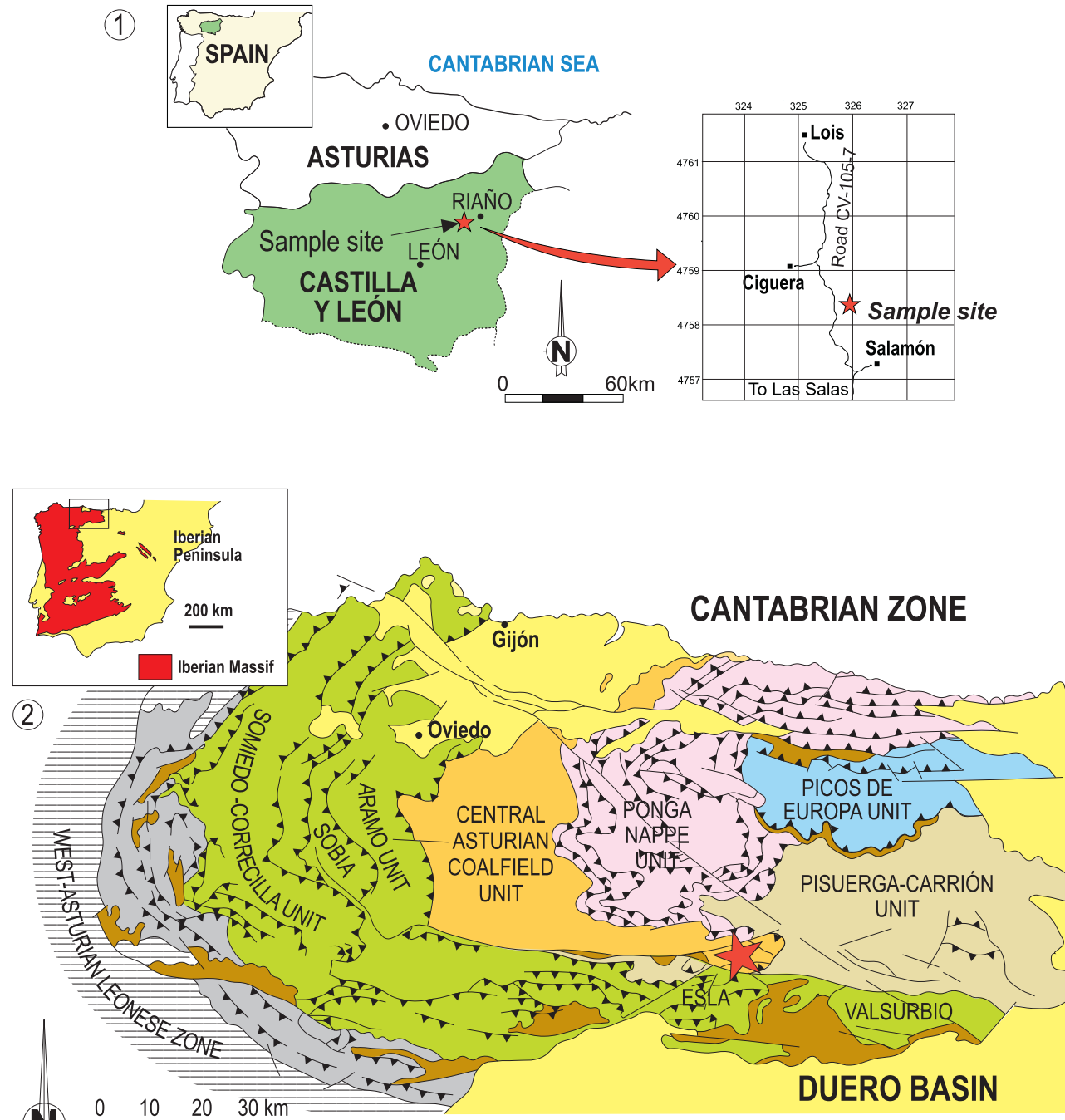

Tectonostratigraphic units of the Cantabrian Zone

\begin{tabular}{|c|c|c|}
\hline Permian-Mesozoic-Tertiary & Fold and Nappe & Picos de Europa \\
\hline Unconformable Stephanian & Central Asturian Coalfield & Pisuerga-Carrión \\
\hline $\begin{array}{l}\text { Narcea Antiform } \\
\text { (Precambrian) }\end{array}$ & Ponga Nappe & Loi \\
\hline
\end{tabular}

FIGURE 1. 1, Geographical setting of the collection site, a roadcut on the eastern side of the Salamón-Lois road (León, NW Spain). 2, Geological sketch map of the Cantabrian Zone showing the location of the Lois-Ciguera sector (modified from Pérez-Estaún et al., 1988).

(Colmenero et al., 2002). It was mostly filled by thick siliciclastic and paralic wedges that pass laterally into limestones. These limestones were deposited on high-rising carbonate platforms in the slowly subsiding most distal areas (Della Porta et al., 2004; Bahamonde et al., 2007; among others).

The Bachende Formation (late Kashirian/early Myachkovian) represents a delta-top carbonate platform developed on the distal shelf areas of the foreland basin. Landward (to the W), carbonate platform sediments alternate and interfingered with deltaic sandstones and shallow marine mudrocks (Lena and Sama Groups). Distally (to the E), the carbonate platform overthrusts the siliciclastic succession of the Pisuerga-Carrión Province that is composed mostly of basinal mudrocks with local turbidites and olistoliths. The Bachende Formation is sandwiched between two major and relatively shallow-water clastic units. The Bashkirian, Lois Formation, a thick (300-700 m) interval composed of mudrocks and some sandstones underlies the Bachende Formation, and it is overlain by the 


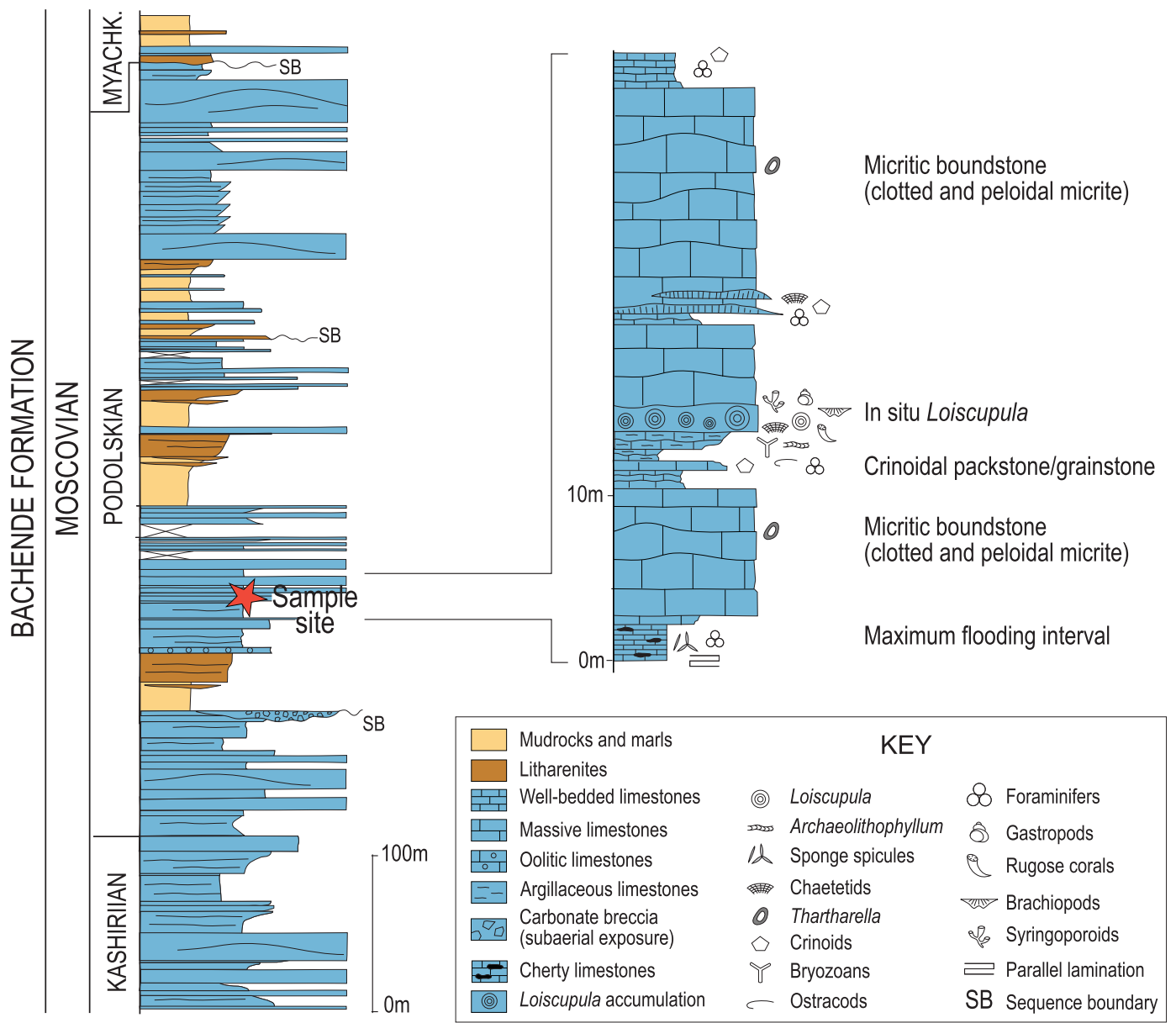

FIGURE 2. Schematic section of the Bachende Formation showing the stratigraphic position of the type locality.

Dueñas Formation, a $300 \mathrm{~m}$ thick succession of deltaic siliciclastics, with some interbedded limestones at the base.

Over $650 \mathrm{~m}$ of shallow subtidal limestones and deltaic siliciclastics compose the Bachende Formation and cycles of stacked shallowingupward, metre-scale (10.6 $\mathrm{m}$ average thickness) sequences, with a moderate amplitude $(\sim 40 \mathrm{~m})$, and high-frequency (15-110 ky) can be recognized (Corrochano et al., 2012). These cycles compose the basic genetic unit of the platform and can be grouped into three major depositional sequences that are bounded by extensive subaerial unconformities. In situ specimens of Loiscupula in the Bachende Formation appear only in the highstand system tract of the second major sequence (late Podolskian) and are located $13 \mathrm{~m}$ above the maximum flooding surface (Figure 2). This sequence ( $200 \mathrm{~m}$ thick) is characterized by a basal carbonate, dominated by oolitic grainstones and bioclastic wackestones/packstones, and an upper part, composed of several mixed carbonate-siliciclastic cycles, with conspicuous micritic boundstones at the base. Loiscupula specimens occur in two lithologies: 1) a lower one, composed of crinoidal packstones/grainstones with abundant fenestellid bryozoans and sparse and broken fragments of Loiscupula (a winnowing occurrence); and 2) an upper one, of bioturbated and argillaceous wackestones (minor packstones), with fragments and complete specimens in presumed life position of Loiscupula (an in situ occurrence).

Organisms occurring with in situ Loiscupula are: phylloid algae (Archaeolithophyllum lamellosum), encrusting algae (Claracrusta), crinoids, brachiopods, bryozoans (fistuliporid and fenestellid), laminar chaetetids, ostracods, syringoporid corals, colonial rugose corals, gastropods, stacheinacean algae (problematic red algae), Shamovella and diverse foraminifers (paleotextulariids, Ozawainella, Tetrataxis, Palaeonubecularia, calcitornellids, lasiodiscids and Tuberitina). The matrix is a homogeneous micrite, with some microsparite. 
The lithology immediately overlying the in situ Loiscupula is a massive micritic boundstone, characterized by a clotted and peloidal micrite resulting from microbial activity (auto-micrite sensu Wolf, 1965; Reitner and Neuweiler, 1995) and homogeneous micrite with scattered bioclasts (allomicrite). The biota associated with this lithology is mainly small crinoid ossicles, agglutinated worm tubes (Thartharella or Therebella) and calcified cyanobacterial filaments of Girvanella. The contact between the substrate containing in situ specimens of Loiscupula and the smothering lithology, is an irregular, sharp non-erosional surface, suggesting that Loiscupula was smothered by the microbial assemblage that produced the microbial boundstone.

\section{SYSTEMATIC PALAEONTOLOGY}

Class Demospongiae Sollas, 1875

Order and Family Incertae sedis

Genus Loiscupula gen. nov.

zoobank.org/09CC7537-3F98-4AA9-BD71-7297F60E061E

Type species. Loiscupula bachendensi gen. nov. sp. nov. Loiscupula is a monotypic genus, established to include $L$. bachendensi.

Etymology. The name is derived from a village close to the collection site (Lois), and the cupshape of the individual specimens.

Diagnosis. Specimens with round, concentric and platy basal skeleton, with cylindrical and branching features (extended mamelons/chimneys) growing upward. Basal skeleton with polygonal to round tubules arranged perpendicular to skeleton producing a honeycomb pattern; tabulae irregularly spaced. Skeletal growth by intertubule increase and peripheral expansion. Inferred spicules, monoaxon oxea (some styles) and polyaxons, occur without a preferred orientation within the basal skeleton.

\section{Loiscupula bachendensi sp. nov.} Figures 3-8

\section{zoobank.org/0F641EBF-75A6-4735-B927-F180F0D7AA5C}

Etymology. The species name derives from the Bachende Formation.

Holotype. USAL LB1 (Figures 3.2-3.6, 4.5, 4.6). Complete specimen.

Type locality. León, Spain, in a roadcut on the east side of the Salamón-Lois road, $1 \mathrm{~km}$ south-western of the small village of Ciguera, León (UTM coord. 325555/4758054), (Figure 1.1).
Occurrence. Currently, Loiscupula is only known from the late Moscovian, Pennsylvanian, Carboniferous, in the Cantabrian Zone, NW Spain.

Diagnosis. As for the genus.

Description. Plate-like forms that vary considerably in size; up to $5 \mathrm{~cm}$ high, $32 \mathrm{~cm}$ across, and from 0.7 to $2.9 \mathrm{~mm}$ thick in cross section, averaging $1.1 \mathrm{~mm}$. Laterally, the skeleton is a flat cupshape, with the central part several centimetres lower than the outer edges (Figure 3.2). A series of regular rings around a central point on the underside of the plate-like skeleton are produced by a regular pattern of concentric grooves and ridges (Figure 3.4). The symmetry of most specimens is exceptionally regular, although in some the central point is tilted to one side. These plate-like skeletons may have more than 15 concentric rings, each one about $1.5 \mathrm{~cm}$ across and $1 \mathrm{~cm}$ high. Conical structures $(2.2 \mathrm{~cm}$ length and $1 \mathrm{~cm}$ diameter, Figure $3.5,3.6)$ are concentrically distributed around the basal surface, although they are usually preserved as eroded protuberances (truncated cones) $1 \mathrm{~cm}$ across and $0.6 \mathrm{~cm}$ high, tilted approximately $30^{\circ}$ towards the central base (Figure 3.6). These features are unevenly spaced in each ring and increase in number toward the outer rings of the fossil. In the holotype, the number of these features in each ring is (from the inner to the outer ring): 3, 5, 7, 10 and 13 (Figure 3.4).

Cylindrical features, which are similar to extended mamelons/chimneys reported in other chaetetids (West, 2011b, 2011c), occur sporadically on the upper surface of the plate-like skeleton (Figure 3.7, 3.8). They are simple or branched, and can reach a length of at least $3.4 \mathrm{~cm}$. An internal cavity within these features is filled with a micrite matrix or with a sparry calcite mosaic. Their outer diameter is up to $5 \mathrm{~mm}$, whereas the inner diameter is up to $3.1 \mathrm{~mm}$.

The internal structure of Loiscupula bachendensi (Figure 4.1-4.8) is composed of narrow polygonal (some hexagonal) to slightly rounded tubules in transverse section, with shared walls between adjacent units. They are straight or gently curved in longitudinal section, and are arranged perpendicular to the surface of the skeleton resulting in a characteristic honeycomb pattern (Figure 4.1). The tubules may be partitioned horizontally at different levels by poorly developed tabulae that may occur at the same or different levels as those in adjacent tubules (Figure 4.2, 4.5-4.8). The tubule walls are approximately 10-15 $\mu \mathrm{m}$ thick, with a $70-120 \mu \mathrm{m}$ cross-sectional area (averaging 


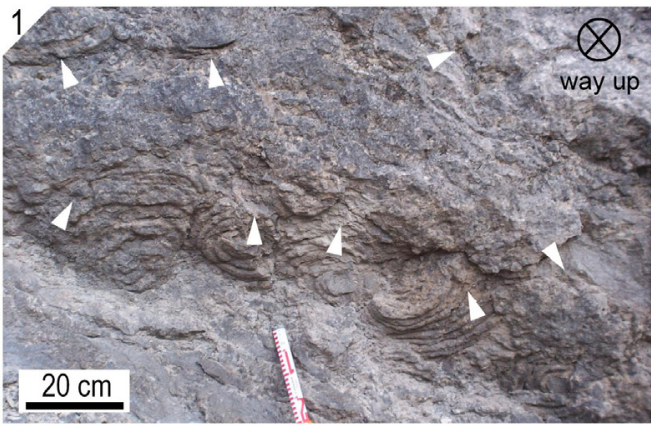

2
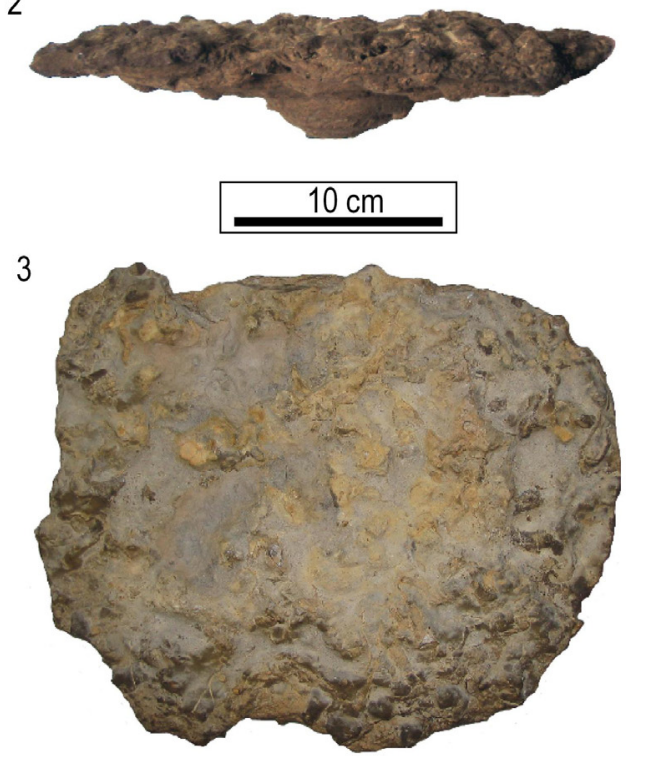

4

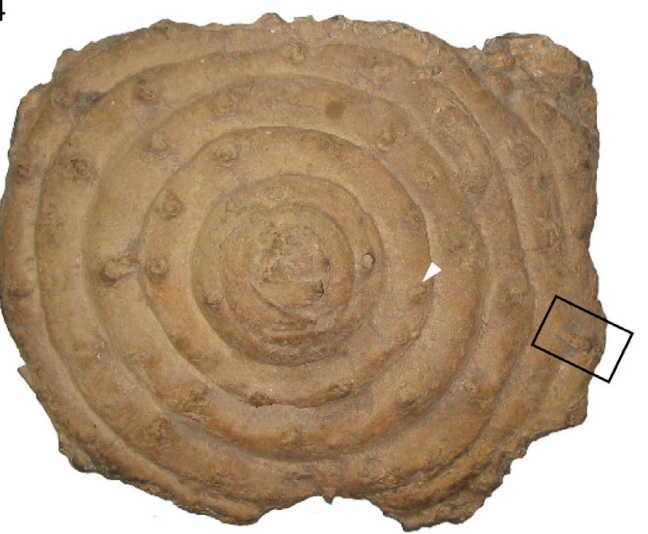

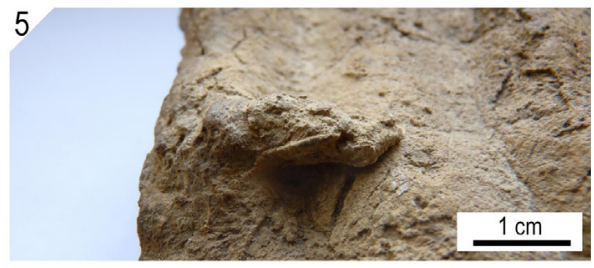
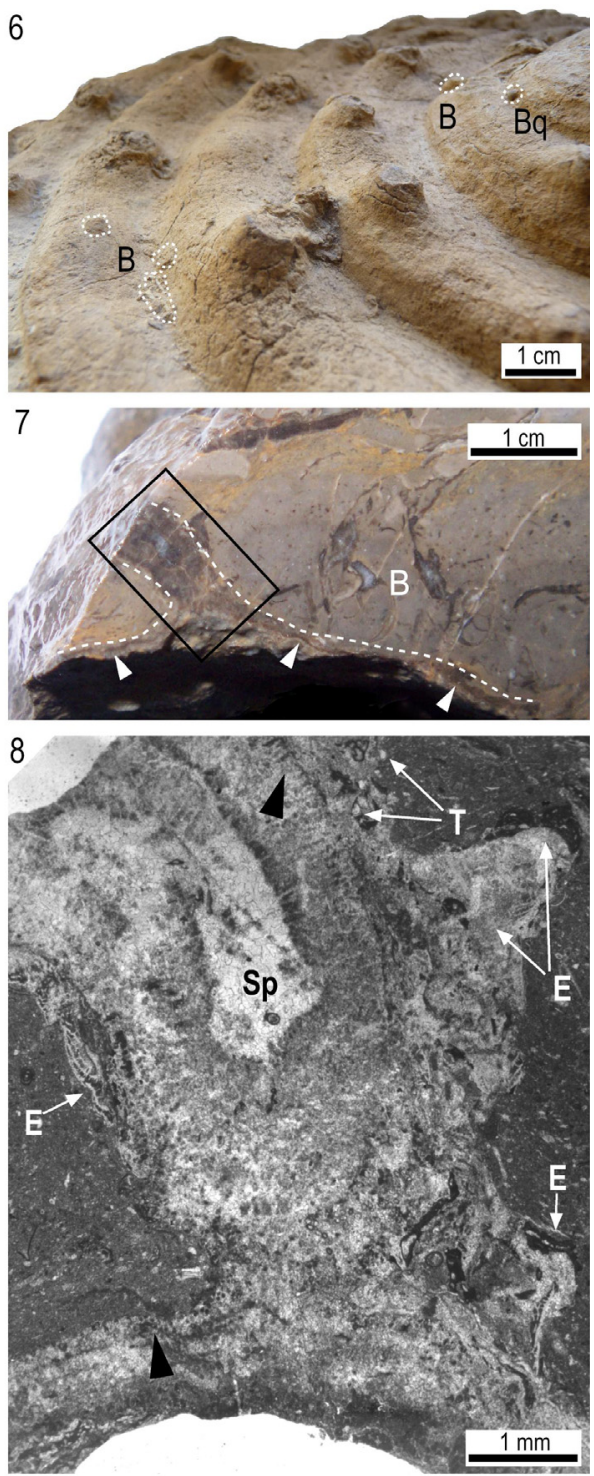

FIGURE 3. General morphologic features of Loiscupula bachendensi gen. nov. sp. nov. from the Bachende Formation, Cantabrian Zone, NW Spain. 1, type locality of Loiscupula bachendensi in the Bachende Formation, arrows point to different specimens. 2-6 Holotype USAL LB1, 2, side view showing the flat cup-shaped skeleton, with the central part of the specimen lower than the outer edges. 3 , top view, showing the wackestone matrix filling the cup. 4, underside of the sponge, showing the plate-shape and the concentric rings around a central point; note the projected structures developed within each ring and usually preserved as eroded (truncated) protuberances (arrow). 5, enlargement of the rectangular area in Figure 3.4, showing in detail one of the projections on the underside of the specimen. 6 , close-up of the undulating underside of the skeleton, showing the eroded protuberances and encrusting bryozoans; $\mathrm{B}=$ bryozoans, $\mathrm{Bq}=$ brachiopod. 7-8, Paratype USAL LB5, 7, cylindrical feature (rectangle) growing up from the upper surface of the skeleton of Loiscupula (white arrows); $\mathrm{B}=$ brachiopod. 8, close-up of the rectangular area in Figure 3.7; arrows point to the poorly preserved microstructure of Loiscupula. Note the abundant foralgal encrustations $(\mathrm{E}) ; \mathrm{T}=$ Tuberitina; $\mathrm{Sp}=$ sparry calcite. 

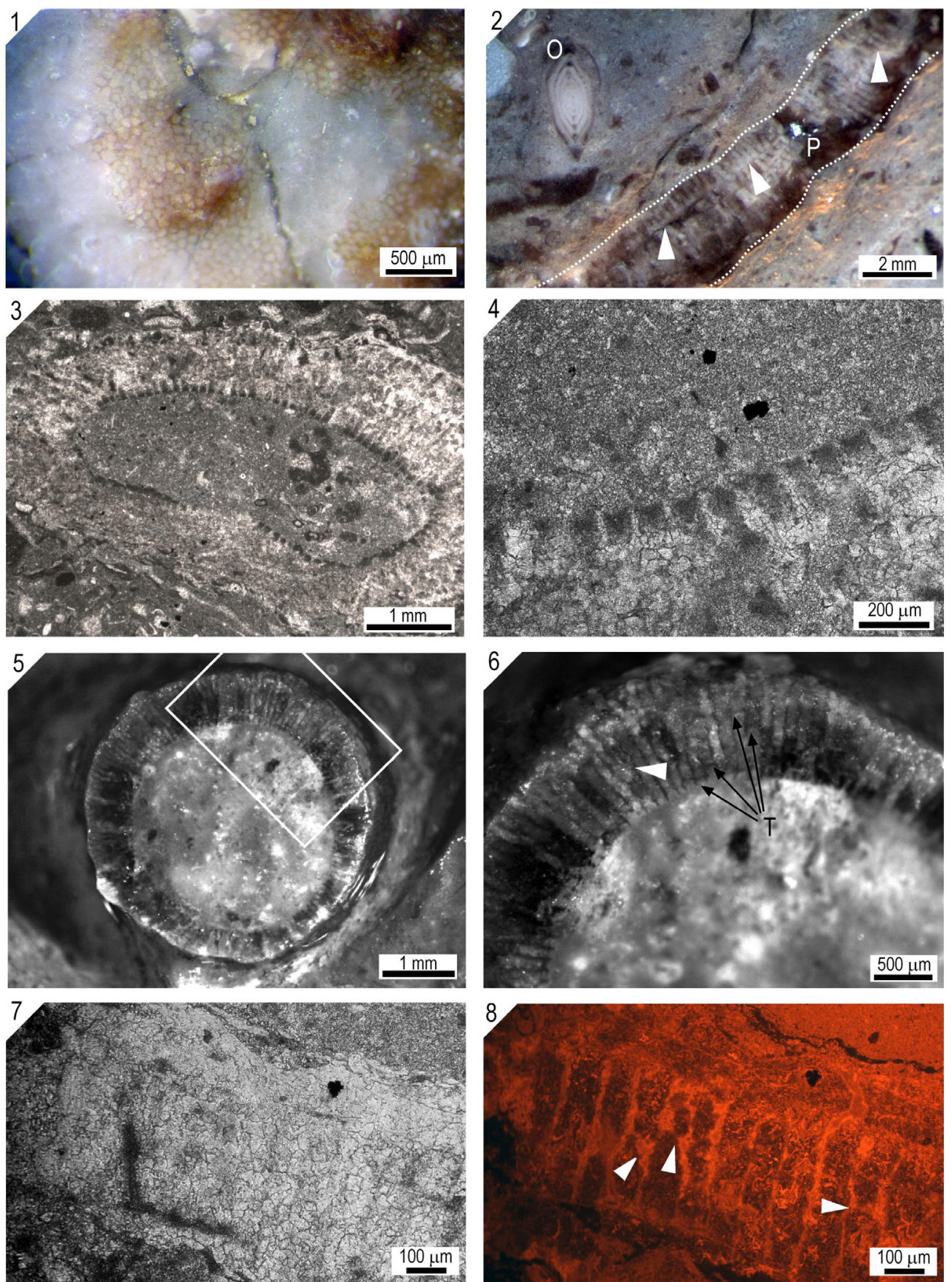

FIGURE 4. Internal structure of Loiscupula bachendensi gen. nov. sp. nov. 1, paratype USAL LB22, close-up showing the honey-comb pattern of the surface of Loiscupula bachendensi. 2, paratype USAL LB5, internal structure of the plate-like basal skeleton (enclosed by white dashed lines); white arrows point to vertical growth interruptions of the tubules; $\mathrm{O}=$ Ozawainella; $\mathrm{P}=$ pyrite. 3-4, paratype USAL LB29, 3, photomicrograph showing the internal structure of a cylindrical feature developed on the upper surface of the skeleton. 4, close-up of tubules at the upper edge of the skeleton. 5-6, Holotype USAL LB1, 5, transversal section of a cylindrical form; note the internal cavity, filled-up with micritic matrix, and the internal structure of Loiscupula composed of tubules. 6, close-up of the rectangular area in Figure 4.5 (rotated $45^{\circ}$ counterclockwise); note the increasing of new tubules by intertubule increase (white arrow) and their horizontal partitions at different levels ( $T=$ tabulae). 7-8, paratype USAL LB5, 7, plane polarized light photomicrograph showing the overall recrystallization of the basal skeleton. 8, cathodoluminescence image of same field of view as Figure 4.7, showing the internal structure of the skeleton with development of poorly defined tabulae (arrowed). 

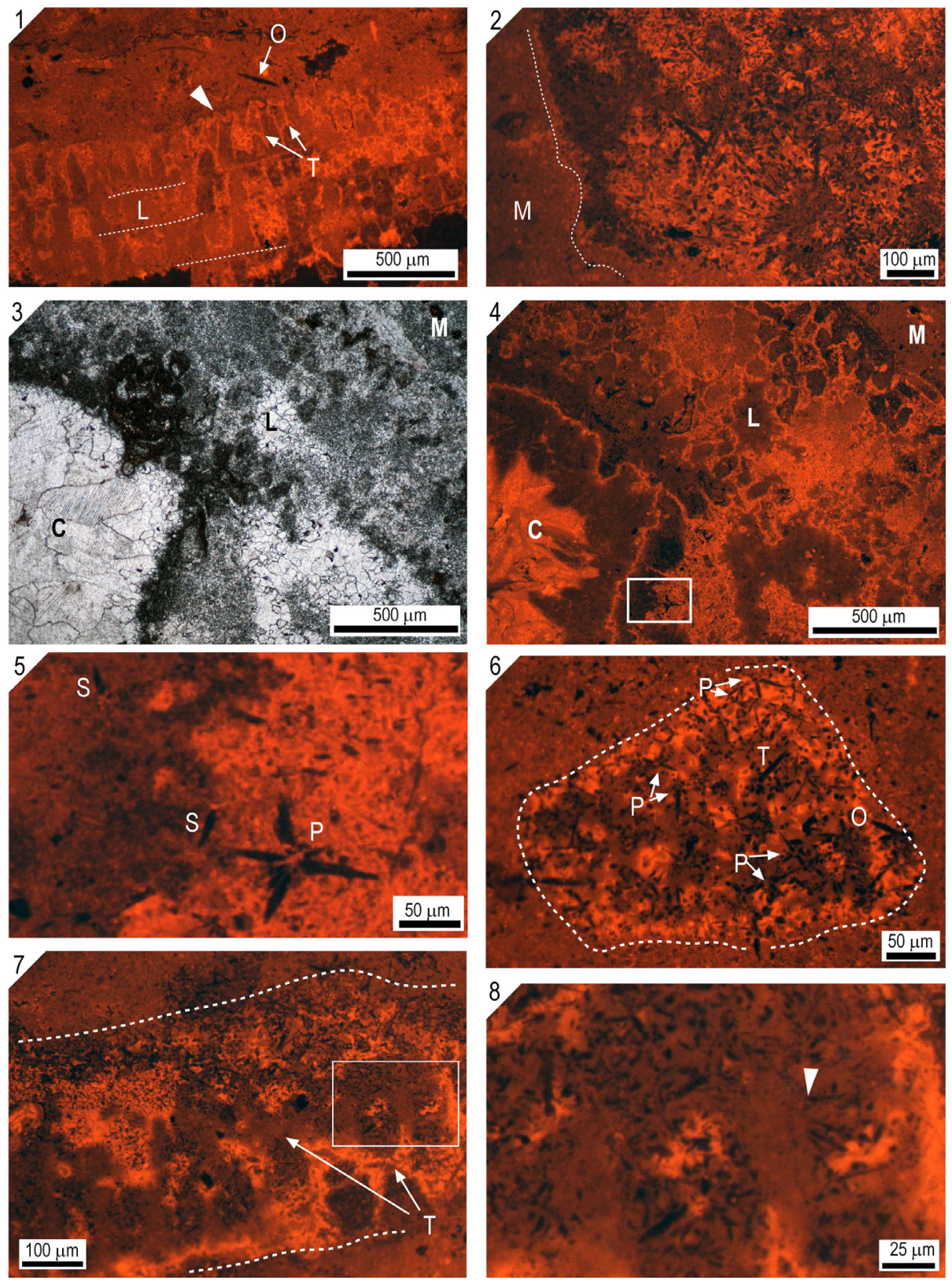

FIGURE 5. 1-8, Paratype USAL LB 5, spicule pseudomorphs of Loiscupula bachendensi gen. nov. sp. nov. All the images, except Figure 5.3, are cathodoluminescence photomicrographs. 1, Oxea (O) spicule pseudomorph floating in the surrounding matrix; white arrow is pointing to an (algal?) encrustation on the upper surface of the skeleton; $T=$ tabulae; L=laminae, indicated by white dashed lines; note that tubules may be continuous or discontinuous across the growth interruptions. 2, intraskeletal non-luminescent spicule (mostly oxeas) pseudomorphs in a fragment of Loiscupula; white dashed line indicates the outer edge of the basal skeleton of Loiscupula; $\mathrm{M}=$ micritic matrix. 3, 4, plane polarized light and cathodoluminescence photomicrographs showing the internal structure of the plate-like basal skeleton; $\mathrm{C}=$ void filling cement; $\mathrm{L}=$ Loiscupula; $\mathrm{M}=$ micritic matrix. 5 , close-up of the rectangular area in Figure 5.4 , showing in detail a polyactine $(P)$ and pseudomorphs of style spicules $(S)$ embedded in the basal skeleton. 6 , Oxea $(\mathrm{O})$ and reduced polyaxon $(\mathrm{P})$ spicule pseudomorphs and a probable pseudomorph of tylostyle spicule (T); dashed line indicates a fragment of Loiscupula. Note the dull appearance of the surrounding matrix and the bright to yellow-dull CL of the skeletal calcite. 7, Spicule pseudomophs concentrated towards the upper edge of the basal skeleton; dashed line indicates a transversal section of Loiscupula; $\mathrm{T}=$ tabula. 8, Close-up view of the rectangular area in Figure 5.5; arrow points to spicule pseudomorphs projecting into a tubule. 
$80-90 \mu \mathrm{m}$ ) and a length of up to (at least) $1.9 \mathrm{~mm}$ (Figure 4.3,4.4). New tubules may arise by intertubule increase (Figure 4.6) or peripheral expansion. Growth interruptions are sporadically present in some specimens and define poorly developed laminae (Figure 5.1). Tubules may be continuous or discontinuous across these interruptions (Figure 5.1).

Cathodoluminescence microscopy reveals non-luminescent calcite structures that are interpreted as spicule pseudomorphs (Figures 5 and 6.1-6.5). These spicule pseudomorphs are only found in the Loiscupula horizon and have not been observed in the overlying and underlying rock units. They appear floating in the matrix, embedded in the skeleton of Loiscupula or projecting into the tubules (Figure 5.7, 5.8). These spicule pseudomorphs do not occur in associated calcareous components, such as void-filling cements or phylloid algae (e.g., Archaeolithophyllum). Spicule pseudomorphs are not visible with transmitted polarized light, and under $\mathrm{CL}$ microscopy, they contrast sharply with the bright to yellow-dull $\mathrm{CL}$ calcite of the skeleton of Loiscupula, with the cement filling the tubules spaces (non-luminescent or orange-dull $\mathrm{CL}$ ) and with the surrounding matrix (orange-dull $\mathrm{CL}$ ). These pseudomorphs are found in large numbers toward the upper edge of the skeletons, and they have been observed in both the plate-like skeleton and the cylindrical and branching forms (extended mamelons and/or chimneys) that project upward from the upper surface. Although frequently the distribution of these pseudomorphs is irregular (Figure 5.2), there are occurrences that suggest that a spicular network existed. Monoaxon oxea spicule pseudomorphs predominate, but styles and polyaxon spicule pseudomorphs are also present (Figures 5.5, 5.6, $6.4,6.5)$.

Although the preservation of the spicule pseudomorphs is relatively good, no convincing axial canals have been observed (Figure 6.3); most of the pseudomorphs exhibit dissolution features, such as irregular edges, deep corrosion or reduction of axial rays (Figure 6.5). In addition, some of them are discontinuous. Pseudomorphs of monoaxon spicules are 190 to $24 \mu \mathrm{m}$ long, and 22 to $4 \mu \mathrm{m}$ wide ( 25 spicules measured). Polyaxon spicules have several equal rays radiating from a central point, and are 190 to $64 \mu \mathrm{m}$ long, and 11 to $9 \mu \mathrm{m}$ wide ( 4 spicules measured). The dimensions of the spicule pseudomorphs were taken from an enlarged CL image, and thus are only approximate and probably underestimated. These dimensions are conservative because it is unlikely that the spicule pseudomorphs were sectioned in a plane that allowed viewing their full and real size.

The basal skeleton is a mosaic of sparry calcite, and the degree of preservation is usually best near the upper margin of the skeleton. The original microstructure was almost completely destroyed during diagenesis, although SEM microscopy revealed patches of the relic fascicular penicillatetype microstructure, which is composed of closely packed needles that fan out from points of calcification in a longitudinal view. These needles are usually encased in coarse calcite crystals as a result of diagenetic overprinting (Figure 6.6), and range in diameter from less than one micrometer to two micrometers.

\section{Discussion and remarks}

Hypercalcified chaetetid demosponges are a group with a diverse and complex taxonomic history with different Paleozoic and post-Paleozoic histories (Fischer, 1970; Gray, 1980; West, 2011a) that has been further complicated by Riding (2004) who assigned Solenopora to the chaetetids (for a detailed history of chaetetid taxonomy see Connolly et al., 1989; and West, 2011a).

As summarized by West (2011a), the valid taxonomic placement of chaetetid sponges should be based in (in order of decreasing usefulness): 1) spicule composition and morphology; 2) the original mineralogy and microstructure of the secondary skeleton; and 3) skeletal and morphological features, such as shape, size and arrangement of the tubules, thickness of the tubule walls, thickness of the tabulae, and absence of septa and mural pores. The first and second features are traditionally used at all levels in the classification of sponges. Unfortunately, in most fossil chaetetids skeletons, spicules (or their pseudomorphs) are usually absent (West and Clark, 1983; West, 2011b), and thus, they have not been usually used as diagnostic criteria in most chaetetid taxonomic classifications. This absence may be due to several biological and diagenetical factors, such as the non-incorporation of the spicules into the skeleton or dissolution during diagenesis. The third set of morphological diagnostic criteria is usually available in fossil chaetetids and has been employed in most chaetetid taxonomic classifications. However, it has been demonstrated that some criteria, such as the diameter of the tubes (properly cross-sectional areas of the tubes) and thickness of the tube walls, are not valid to differentiate Carboniferous 

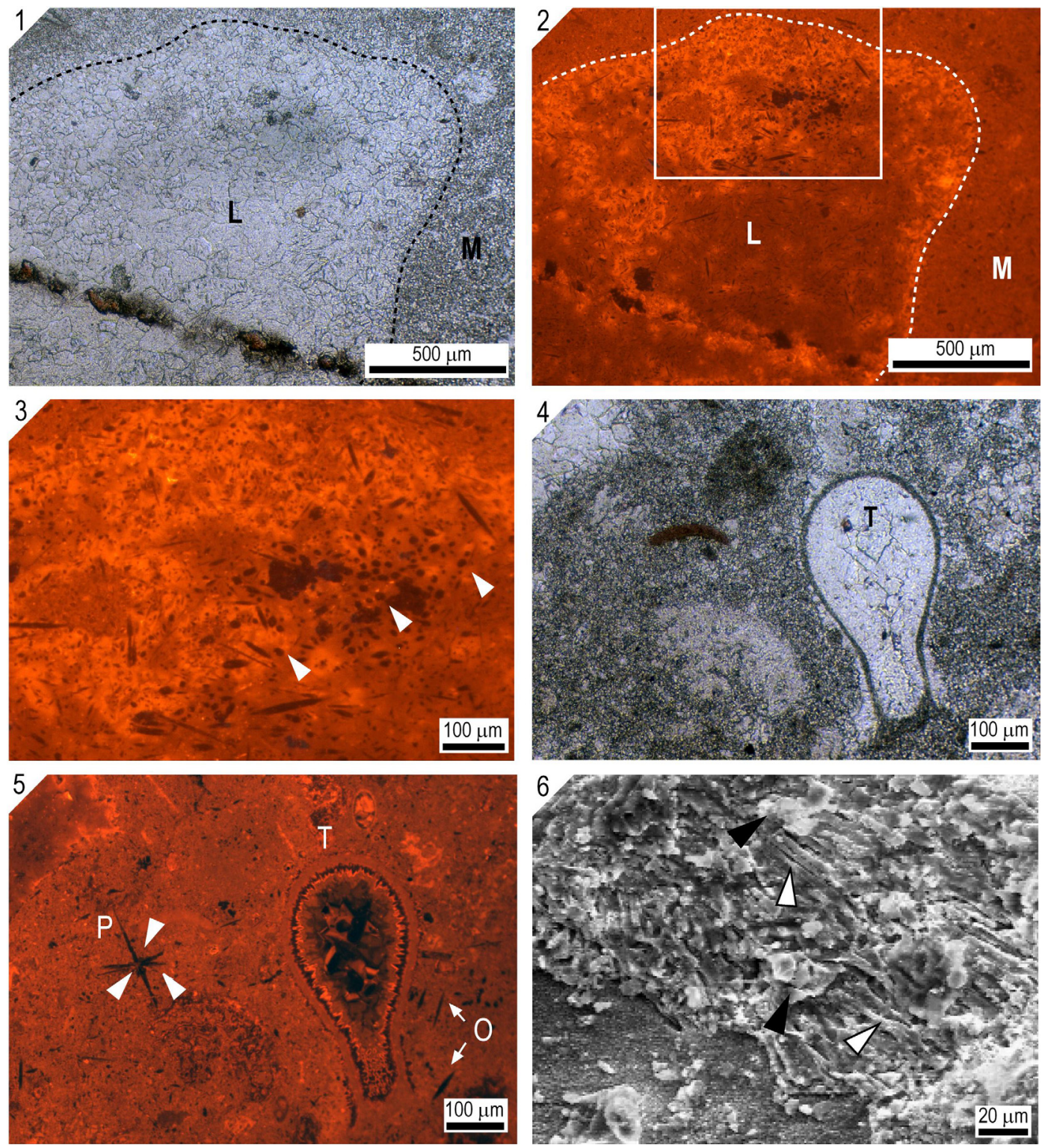

FIGURE 6. 1-6, Paratype USAL LB 5, spicule pseudomorphs and microstructure of Loiscupula bachendensi gen. nov. sp. nov. All the images are cathodoluminescence photomicrographs, except Figure 6.6, which is a scanning electron micrograph. 1, strongly recrystallized fragment of Loiscupula (L) floating in a microspartic matrix (M). 2, cathodoluminescence image of same field of view as Figure 6.1, showing abundant spicule pseudomorphs embedded in the basal skeleton; note that they are absent in the surrounding matrix; $L=$ Loiscupula; $M=$ matrix. 3, close-up of the rectangular area in Figure 6.2, showing in detail several pseudomorphs of oxea pseudomorphs; arrows point to spicule cross sections. 4, 5, plane polarized light and cathodoluminescence photomicrographs showing a Tuberitina specimen $(T)$ with well developed cathodoluminescence zonation; $(P)$ polyaxon spicule pseudomorph floating in the surrounding microsparitic matrix with some rays shortened an others missing (arrows); $\mathrm{O}=$ pseudomorphs of oxea spicules with irregular edges. 6 , Relic fascicular penicillate microstructure of Loiscupula, composed of fibers, inferred to be aragonite needles (white arrows) within coarse calcite crystals (black arrows).

species of the genus Chaetetes (West 1994, 2011a).

Currently, there are 22 chaetetid genera and subgenera from which spicule pseudomorphs, and the original microstructure and mineralogy of the basal skeleton, have been reported (West 2011a, table 3). Calcite, silica or pyritic monoaxoan spicule pseudomorphs (mainly tylostyles or styles) in Carboniferous chaetetids have been reported in Chaetetes (Boswellia) by Gray (1980), from the 

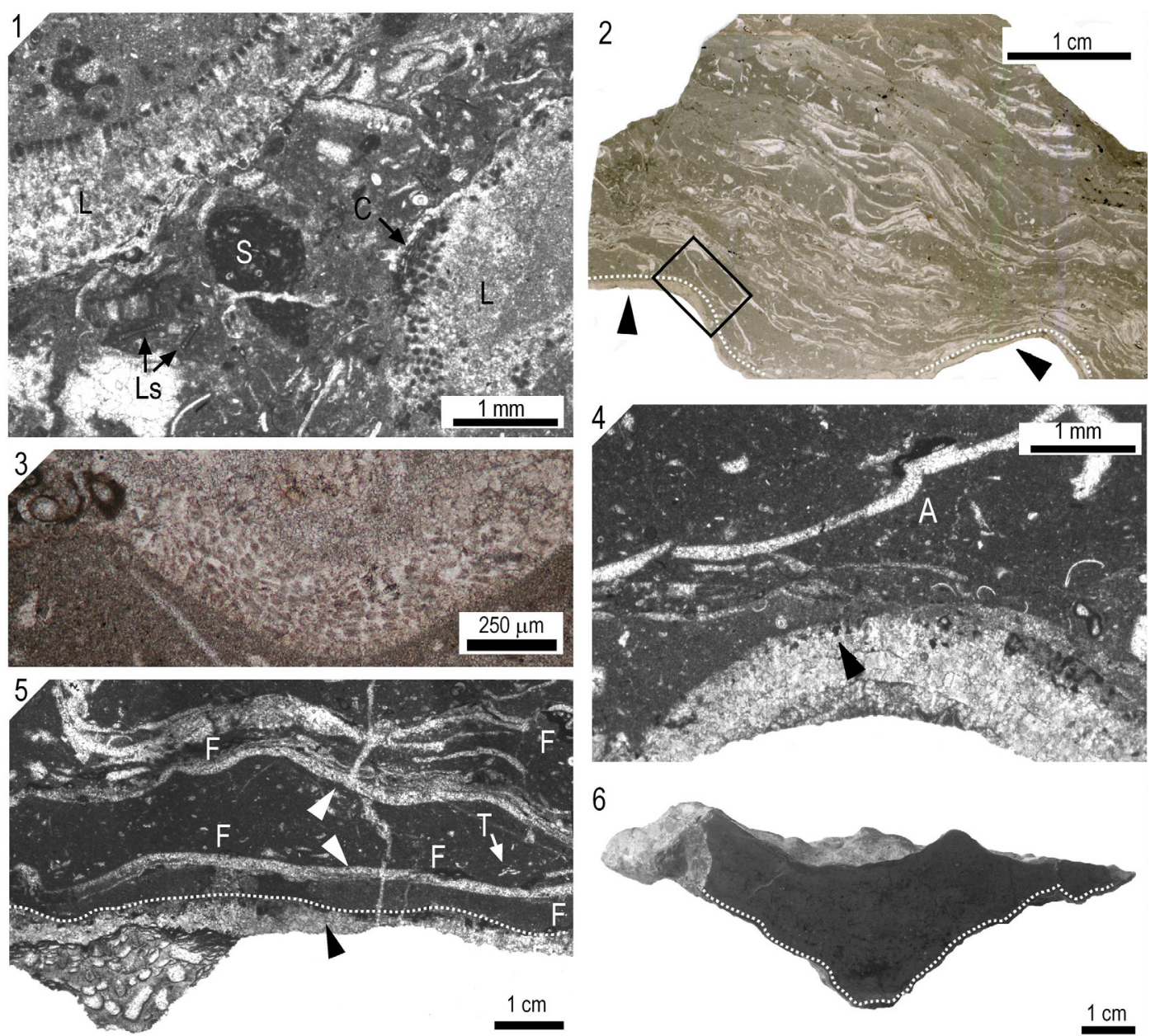

6

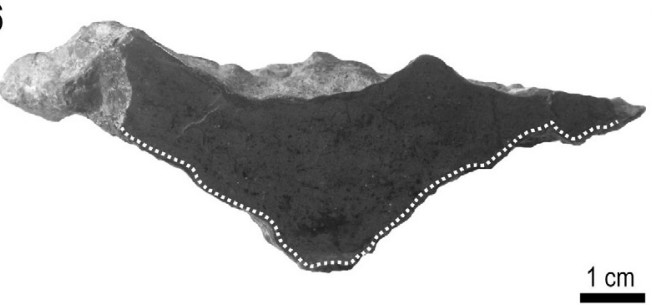

FIGURE 7. 1, Paratype USAL LB 5, Loiscupula (L) fragments floating in a muddy matrix; Ls= lasiodiscids; C=cyanobacteria filaments (Girvanella?); S= Shamovella. 2-4, USAL LB34, 2, polished slab showing the matrix that filled the cup-like skeleton of Loisphyllum (arrowed), with a complex intergrowth of Archaeolithophyllum lamellosum; note the undulating morphology of the Loiscupula skeleton (white dashed lines), representing the circular and concentring rings (grooves and ridges) in transverse section. 3, Archaeolithophyllum thallus showing relics of coaxial perithallum and hypotallum organization. 4, close-up view of the rectangular area in Figure 6.2; note the neomorphic calcite forming the basal skeleton and the poor preservation of the tubules (arrow); A= blade fragments of Archaeolithophyllum. 5, paratype USAL LB38-1, polished slab of a Loiscupula bachendensi specimen (black arrow and dashed line) with a fistuliporid bryozoan encrusting (lower left of the image) the underside of the specimen; note the development of the complex intergrowth of Archaeolithophyllum lamellosum (white arrows) in the wackestone matrix and the encrustations of small foraminifers (F), usually developed on the upper surface of the phylloid blades and Loiscupula. T= small specimen of Tetrataxis. 6, paratype USAL LB24, transversal section of a small specimen of Loiscupula bachendensi, showing the internal wackestone matrix filling the cup-shaped skeleton (dashed lines).

British Dinantian. Loiscupula bachendensi differs from these chaetetids in containing oxea, style and polyaxon spicules forming a complex and irregular network, and justifies the new genus and species as described herein. Furthermore, the extremely regular and concentric basal skeleton, the occurrence of ventral projections (actually preserved as eroded protuberances), and the inferred central point of attachment, are features not reported in other chaetetid hypercalcified sponges. Until the composition of the original microstructure of Loiscupula and the type and arrangement of spicules are better known, the taxonomic placement of these fossils within the Class Demospongiae is uncertain.

Alternatively, although the spicular objects are best candidates for spicule pseudomorphs and Loiscupula shows numerous similarities with other 


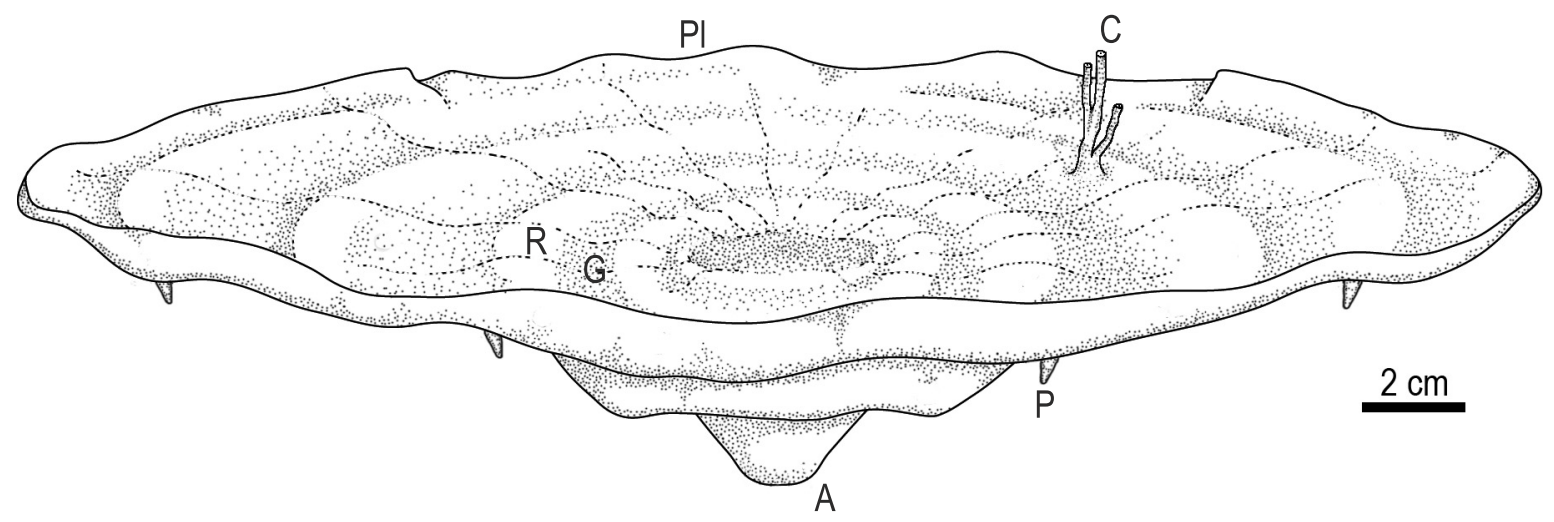

FIGURE 8. Idealized reconstruction of Loiscupula bachendensi gen. nov. sp. nov. Note the low conical growth form; $A=$ presumed attachment point; $P=$ projections on lower surface; $G=$ grooves; $R=$ ridges; $P I=$ plate-like skeleton; $C$ )= cylindrical/branching features (extended mamelons/chimneys) on upper surface.

chaetetid demosponges, there is not conclusive evidence to verify the original silica composition of the spicules. Thus, these pseudomorphs could represent in reality diagenetic alteration of originally calcareous spicules. In that case, the systematic placement of Loiscupula within the Demospongiae would be invalid.

\section{MINERALOGY, PRESERVATION AND DIAGENESIS OF LOISCUPULA}

Fossil and extant coralline sponges secrete metastable carbonate like high-Mg calcite (e.g., Merlia, Acanthochaetetes, Stromatoaxinella) or aragonite (e.g., Chaetetes (Boswellia), Astrosclera, Ceratoporella), and thus, both are possible as the mineralogy of Loiscupula. Several studies have demonstrated that the alteration of high-Mg calcite to low-Mg calcite usually retains, to a high degree, the details of the original skeletal structure because the change does not involve a modification of the original crystal habit (e.g., James and Choquette, 1983; Tucker and Wright, 1990). On the other hand, early diagenetic process (usually under vadose/meteoric phreatic conditions) that converts aragonite to calcite often results in a secondary fabric formed by a mosaic of coarse-grained neomorphic spar. This mosaic commonly retains only the basic structure of the original elements, usually as organic inclusions (e.g., James, 1974). In some instances, the replacement is incomplete, and tiny crystallites of aragonite remain as relics entombed in the new calcite (Sandberg et al., 1973; Sandberg and Hudson, 1983).

The skeleton of Loiscupula bachendensi is now composed of a sparry calcite mosaic, and the skeletal fabric is poorly preserved, but with relics of fascicular needles encased in coarse calcite crystals. Based on these observations, it is inferred that the original mineralogy of Loiscupula was probably aragonite that has undergone diagenetic alteration. In addition, the preservation of the outlines of the original structure and relics of remnant aragonite needles, suggests that the transformation process was the result of a rapid and in situ replacement of the aragonite, and not removal by solution followed by precipitation of void-filling cement.

Although CL microscopy has not been usually used as a tool to study polymorphic transformations in fossil forms (Boggs and Krinsley, 2006) it has been demonstrated that diagenesis can influence the CL signal. Richter and Zinkernagel (1981) suggested that aragonitic skeletons loose their luminescence zonation during replacement by calcite, whereas $\mathrm{Mg}$-calcite skeletons may maintain part of it because their replacement preserves the original crystal fabric.

Minor element data (Mg, Mn, Fe and $\mathrm{Sr}$ ) from bulk samples of five specimens (Table 1) indicate that the basal skeleton of Loiscupula is currently composed of neomorphosed low-Mg calcite (1.7 mol $\% \mathrm{MgCO}_{3}$ ). In all the samples, Fe values are relatively high (with an average of $5468 \mathrm{ppm}$ ), whereas $\mathrm{Mn}$ diagenetic enrichment appears to be insignificant (mean of 103 ppm). On the other hand, $\mathrm{Sr}$ content is high, but variable, ranging from 1492 to 3456 ppm (average 2422 ppm). When present at an anomalously high concentration in a calcitic fossil, $\mathrm{Sr}$ is often taken to be the chemical remnant of a primary aragonite composition (Sandberg and Hudson, 1983). Recent skeletal aragonite in coralline demosponges typically contains 8000 10000 ppm Sr (Laghi et al., 1984; Mastandrea and 
TABLE 1. Minor element content (ppm) of Loiscupula skeletons from the Bachende Formation.

\begin{tabular}{lcccc}
\hline \multicolumn{1}{c}{ Type (ppm) } & Mg & Mn & Fe & Sr \\
\hline USAL LB2 & 3821 & 60 & 4246 & 2863 \\
USAL LB4 & 3804 & 168 & 8477 & 1943 \\
USAL LB5-5 & 4535 & 103 & 5717 & 2365 \\
USAL LB5-13 & 5033 & 119 & 4636 & 1482 \\
USAL LB22 & 4423 & 66 & 4266 & 3456 \\
\hline Average & 4323 & 103 & 5468 & 2422 \\
\hline
\end{tabular}

Russo, 1995; Reitner et al., 2001). Nevertheless, the diagenetic stabilization of aragonite commonly results in a $\mathrm{Sr}$ depletion because its incorporation in the calcite lattice is not favoured. Given that, the $\mathrm{Sr}$ values of Loiscupula are reasonably similar to the $\mathrm{Sr}$ values reported for other Pennsylvanian aragonitic fossils as follows: $1800-3500 \mathrm{ppm} \mathrm{Sr}$ for encrusting demosponges in Texas (Molineux, 1994), $4000 \mathrm{ppm}$ Sr for cephalopods and 4800$5200 \mathrm{ppm} \mathrm{Sr}$ in molluscs from the Kendrick Shale of eastern Kentucky (Uwe, 1981). However, the Sr values for the skeleton of Loiscupula are much lower than the Pennsylvanian data reported by Dickson et al. (1996) for exceptionally preserved demosponges in New Mexico (7600 ppm Sr), or by Kirkland et al. (1993) for very well preserved Eugonophyllum specimens from the Sacramento Mountains (9090 ppm Sr), which retain abundant relics of aragonite needles, with $\mathrm{Sr}$ concentrations close to the concentrations of unaltered aragonite.

The tubules of Loiscupula are filled with finegrained equant cements that are non-luminescent or orange-dull CL. Based on their form, size and occurrence (e.g., Figure 4.4, 4.7, 4.8) they are interpreted to have been originally calcite that had a low $\mathrm{Sr}$ content. Because it was not possible to separate the calcitic skeleton from early diagenetic cement that fills the tubules, the ICP-MS results indicate an alteration of the original chemistry of the basal skeleton. Therefore, the $\mathrm{Sr}$ in the specimens of Loiscupula probably shows a reduction due to diagenetic contamination.

It is suggested that the elevated content of $\mathrm{Fe}$ was derived from the tubule-filling cements, which reflect subsequent diagenetic changes from reducing fluids enriched in Fe. This interpretation is consistent with the observed cathodoluminescence signal, because the absence of luminescence is usually related to high concentrations of $\mathrm{Fe}^{2+}$ that appears to be the most important quencher of luminescence in natural carbonates (e.g., Machel et al., 1991; Boggs and Krinsley, 2006). The source of Fe is probably related to the burial transformation of detrital clays accompanied by release of metal ions to the pore fluid. Such clays/mudstones occur in the middle part of the Bachende Formation (Figure 2 ) and the overlying Dueñas Formation.

The non-luminescent spicule-like structures reported herein, which are missed using conventional microscopy, are reasonable candidates for sponge spicule pseudomorphs. An alternative, however, would be that some of them, especially the polyactine forms, may represent in reality authigenic crystals formed during early diagenesis. Although their size and morphology do not rule out this possibility, the presence of these structures only within the fragments of Loiscupula and not in other recrystallized bioclasts (e.g., the red alga Archaeolithophyllum) or diagenetic cements, suggests that the authigenic crystal interpretation is improbable.

It is widely accepted that the primary mineralogy of chaetetids spicules was opaline silica (see review in Gray, 1980; Cremer, 1995; West, 2011b) that was easily and rapidly dissolved, with the resulting molds, in some cases filled by other secondary minerals (e.g., calcite, silica, pyrite). Such rapid dissolution has been observed in recent hypercalcified sponges and can occur during life (Hartman and Goreau, 1970, 1972; Reitner, 1987). After the dissolution of opaline silica, while the spicules existed as molds in Loiscupula, many molds were deformed. The molds were subsequently filled and cemented by non-luminescent calcite that contrasts sharply with the bright and yellow-dull luminescent calcite of the secondary skeleton (Figures 5 and 6.1-6.5). The edges of some pseudomorphs are irregular and corroded, features that were filled with dull luminescent calcite, indicating diagenetic processes that postdated their cementation.

The diversity of spicule morphology in Loiscupula specimens invites discussion. Some of the spicules are discontinuous, a feature suggesting severe corrosion (as suggested by Gray, 1980). The irregular edges and shapes of some spicule 
pseudomorphs are the result of diagenetic processes. Consequently, most of the oxea calcite pseudomorphs could have originally been styles (tylostyle?) or reduced derivations of polyaxon spicules.

The timing of the calcite cementation of the tubules must have occurred prior to dissolution of the siliceous spicules to allow the formation of molds that produced the spicule pseudomorphs, as noted by Wood and Reitner (1988) in specimens of Stromatoaxinella. However, the cement in some tubules masks the walls of the tubules and some spicule pseudomorphs, suggesting that diagenetic alteration has occurred. The timing of the cementation of the spicule pseudomorphs relative to the neomorphism of aragonite to low-Mg calcite is uncertain and requires further geochemical studies, but based on $\mathrm{CL}$ observations, it can be assumed that it was not contemporaneous. This assumption is in agreement with the diagenetic pathways reported by Gray (1980) in some specimens of Chaetetes (Boswellia) from the Carboniferous.

\section{PALAEOECOLOGY}

The ecology of extant hypercalcified sponges is fundamentally different from that of fossil forms. Extant forms are commonly found in cryptic habitats such as submarine caves of the reef core, and at depth on fore-reef slopes and walls in both the Caribbean and Indo-Pacific regions (Hartman and Goreau, 1975) in depths ranging from 10 to $185 \mathrm{~m}$ (Fallon et al., 2005). In contrast, Palaeozoic chaetetids are common open-shelf organisms, often associated with sunlight and relatively shallow-water carbonates. Therefore, the transfer of ecologic data from extant hypercalcified sponges to fossil chaetetids is tenuous and tentative, and the palaeoecology of Loiscupula must be inferred from the associated biota and sedimentologic evidence.

\section{Fossil Assemblage}

The relatively highly diverse fossil assemblage associated with Loiscupula in the micritic matrix, includes diverse foraminifers, brachiopods, crinoids, ostracods, calcareous algae, syringoporid corals, colonial rugose corals, gastropods, stacheinacean algae, cyanobacteria and bryozoans (Figure 7.1). Such an assemblage is indicative of open marine conditions, with normal salinity and well oxygenated water.
Archaeolithophyllum lamellosum generally encrusts the upper surface of Loiscupula forming undulatory masses of superimposed crusts or thalli up to $2 \mathrm{~cm}$ thick, oriented subparallel to the bedding surface (Figure 7.2-7.4). It is usually associated with Shamovella and Palaeonubecularia, forming complex intergrowths in the micritic matrix. The conspicuous presence of $A$. lamellosum suggests a depositional environment within the euphotic zone. Wray (1964) described wave-resistant features formed by $A$. lamellosum, and its abundance could be indicative of environments of high to moderate energy.

Large benthic foraminifers, such as paleotextulariids, inhabited shallow and warm environments with moderate to strong hydrodynamic conditions (Gallagher, 1998; Della Porta et al., 2005; MerinoTomé et al. 2009). Ozawainella (Figure 4.2) is consistent with open marine and outer platform facies below wave base, and in the Cantabrian Zone is usually associated with open-marine crinoidal accumulations (Della Porta et al., 2005). In the Carboniferous and Permian of the USA, Tetrataxis is a common foraminifer of shallow phylloid algal facies (Toomey and Winland, 1973), which was able to live in highly varied environments with a preference for open-marine environments (Della Porta et al., 2005). However, its distribution shows a wider range of depths than most Fusulinida (Gallagher, 1998). Della Porta et al. (2005) reported that tetrataxids in the Sierra del Cuera platform (NW Spain) occur in platform and slope facies and even at aphotic depths of $200 \mathrm{~m}$ below the platform break. Additionally, Cózar and Rodríguez (2003) suggested that the occurrence and abundance of tetrataxids was similar in all facies, but its relative abundance is higher in intertidal and mud mound facies because many other taxa do not inhabit these facies. The lasiodiscids mainly occur in quiet-water, low-energy open marine, subtidal facies and mud mound environments (Cózar and Rodríguez, 2003; Della Porta et al., 2005).

Chaetetids at the type locality are laminar, up to a few centimetres thick and may also encrust the upper surface of Loiscupula. Laminar chaetetids are believed to be better adapted to high-energy environments, although Kershaw and West (1991) suggested that this growth form remains problematic, and an interpretation of its environmental habitat depends on the type and features of the associated lithology. Chaetetids are commonly interpreted to have inhabited very shallow-water subtidal environments, close to intertidal depths where the water is somewhat agitated (Connolly et 
al., 1989; Wahlman, 2002). However, these organisms were probably able to thrive over a range of depths, and chaetetid accumulations have been reported at paleowater depths of approximately $100 \mathrm{~m}$ in Sonora, Mexico (Almazán-Vázquez et al., 2007).

Brachiopods and fistuliporid bryozoans (rarely fenestrate/ramose bryozoans) occur on the lower surface of Loiscupula skeletons (Figure 7.5), and represent cryptic biota associated with small cavities formed between Loiscupula and the substrate. Bryozoan colonies are conical or occur as irregular patches up to $2.2 \mathrm{~cm}$ across and less than $1.5 \mathrm{~mm}$ thick. In the holotype (USAL LB1), these bryozoans cover an average area of only $0.9 \%$ of the lower surface of Loiscupula. The cryptic biota is similar to that reported by Hartman and Goreau (1970) found on extant hypercalcified sponges, and to cryptic faunas documented by Suchy and West (1988) on laminar chaetetids from the Pennsylvanian Pawnee Formation (lowa), and to that reported beneath Silurian stromatoporoids in the Silurian of Gotland, Sweden, by Kershaw (1980). Suchy and West (1988) suggested that although a wide depth range could be plausible for their specimens, the cryptic community probably represents intertidal occurrences similar to those observed on extant specimens of Acanthochaetetes, from well oxygenated marine water of normal salinity.

\section{Growth Mode}

The lithology filling and surrounding the in situ skeletons of Loiscupula, is a wackestone (minor packstone), basically formed by a homogeneous micrite with some recrystallization to microsparite. This occurrence was resulted from the successive vertical accumulation of specimens of Loiscupula and the deposition of muddy sediment. Some algae, such as Archaeolithophyllum, and diverse, encrusting foraminifers, trapped and bound the sediments stabilizing it. These meter thick accumulations lack a positive relief and are interpreted as chaetetid banks.

The facies of the Bachende Formation that contains the in situ specimens of Loiscupula is interpreted as an environment of moderate to low energy, below wave base or a protected area in the shallow water of the platform. This interpretation is supported by the scarcity of grain-supported deposits with current structures. Fragments of Loiscupula in the surrounding matrix and the lithology filling the skeletons are probably the result of turbulent episodes. The orientation of Loiscupula relative to the substrate suggests that it grew very close to the seabed, elevated very little above it. The growth form of Loiscupula is essentially twodimensional (Figures 3.2, 7.6, 8) and therefore it could have come in direct contact with other benthic organisms, competing for space (e.g., calcareous algae). However, the well-developed regular circular geometry in plan view, would suggest that they lived in a relatively uncrowded environment where they were free to grow outward in a very regular fashion. As Loiscupula grew laterally, it also grew vertically, and the growth bands observed in some specimens are interpreted to be phases of such growth. The concentric rings in all the specimens studied, probably indicate successive lateral growth stages of the organism (peripheral expansion) and suggest a regular outgrowth from an initial and central point of settlement/attachment. Although there is no evidence of attachment to the substrate, the base of the skeleton that tapers downward could have served as a peduncule, such as observed in some species of Acanthochaetetes (e.g., Millet and Kiessling, 2009). The ecological function of the ventral projections (now mostly preserved as eroded protuberances) observed on the basal surface of Loiscupula remains uncertain. However, they may have served a support function, or anchoring mechanism, for the growth of the low conical form in the muddy substrate. Substrates on which chaetetids grew were hard, firm, or composed of loose and coarse grains (West and Kershaw, 1991). The absence of pressure-solution features or sutured contacts between grains indicates rapid synsedimentary cementation of the muddy sediment, resulting in a lithified firm substrate for Loiscupula. Early lithification of the substrate is also supported by the upper non-erosive hummocky irregular topography of the Loiscupula occurrence. As pointed by Almazán-Vázquez et al. (2007), such substrates would be favoured by relative strong hydrodynamic conditions that permitted rapid cementation of the granular sediments.

Cylindrical branched forms growing up from the plate-shaped basal skeleton resemble some vertical features observed in fossil chaetetids that are referred to as chimneys (West, 2011b, 2011c). These vertical developed mamelons may be related to exhalent movement of water, although it is also possible that these structures are the result of an associated symbiotic organism (West, 2011c).

\section{CONCLUSIONS}

1. A new chaetetid genus (Demospongiae) is described as Loiscupula bachendensi n. gen. 
n. sp., from the Moscovian Bachende Formation (Cantabrian Zone, NW Spain).

2. Loiscupula has a circular, concentric and platy (low cup-like) basal skeleton, with cylindrical and branching features (extended mamelons and/or chimneys) growing upward. The basal skeleton is composed of polygonal (often hexagonal) to slightly rounded tubules arranged perpendicular to the surface of the skeleton, resulting in the characteristic honeycomb pattern of chaetetids. Tabulae are irregularly distributed and tubules increased by intertubule increase and/or peripheral expansion.

3. Cathodoluminescence microscopy revealed non-luminescent calcite pseudomorphs of oxeas (rarely styles) monoaxon and polyaxon spicules.

4. Despite the fact that the basal skeleton is recrystallized and now composed of a low-Mg calcite $\left(1.7 \mathrm{~mol} \% \mathrm{MgCO}_{3}\right)$, recognition of what appears to be a penicillate microstructure with relics of aragonite needles, and the high $\mathrm{Sr}$ content of the skeleton, supports the interpretation that the original skeleton of Loiscupula was aragonite.

5. Loiscupula lived on or attached to a firm carbonate-mud substrate, and provided small cryptic cavities between its skeleton and the sea floor for encrusting organisms, such as fistuliporid bryozoans. The associated fossil assemblage and sedimentological features support an open marine environment within the euphotic zone for Loiscupula where the normally saline waters were well-oxygenated and where energy conditions were low to moderate.

\section{ACKNOWLEDGMENTS}

Thanks are due to all the individuals who have contributed during the past years to the discussions on the systematic affinity of Loiscupula. Special thanks to E. Villa (Oviedo), for her helpful comments and biostratigraphic studies of fusulinids. P. Barba (Salamanca), O. Merino-Tomé (Oviedo) and I. Hernández-Almeida (Bern) are thanked for all their comments and suggestions and for field assistance. Thanks to I. Armenteros (Salamanca), for his assistance with cathodoluminescence microscopy and discussions on diagenesis. We also are grateful to the two anonymous journal reviewers who provided constructive comments. This research is a contribution to the project CGL2004-02645/BTE of the Spanish Ministerio de Ciencia e Innovación.

\section{REFERENCES}

Almazán-Vázquez, E., Buitrón-Sánchez, B.E., Vachard, D., Mendoza-Madera, C., and Gómez-Espinosa, C. 2007. The late Atokan (Moscovian, Pennsylvanian) chaetetid accumulations of Sierra Agua Verde, Sonora (NW Mexico): composition, facies and palaeoenvironmental signals, p. 189-200. In Alvaro, J.J., Aretz, M., Boulvain, F., Munnecke, A., Vachard, D., and Vennin, E. (eds.), Paleozoic Reefs and Bioaccumulations: Climatic and Evolutionary Controls. Geological Society, London, Special Publications, 275.

Bahamonde, J.R., Merino-Tomé, O., and Heredia, N. 2007. A Pennsylvanian microbial boundstone-dominated carbonate shelf in a distal foreland margin (Picos de Europa Province, NW Spain). Sedimentary Geology, 198:167-193.

Boggs, S.J. and Krinsley, D. 2006. Applications of Cathodoluminescence Imaging to the Study of Sedimentary Rocks. Cambridge University Press, Cambridge.

Colmenero, J.R., Fernández, L.P., Moreno, C., Bahamonde, J.R., Barba, P., Heredia, N., and González, F. 2002. Carboniferous, p. 93-116. In Gibbons, W. and Moreno, T. (eds.), The Geology of Spain. The Geological Society London.

Connolly, W., Lambert, L., and Stanton, R. 1989. Paleoecology of lower and Middle Pennsylvanian (Middle Carboniferous) "Chaetetes" in North America. Facies, 20(1):139-167.

Corrochano, D. 2010. Origen y ciclicidad de las plataformas carbonatadas westfalienses en los sectores de Piedrafita-Lillo y Lois-Ciguera, Zona Cantábrica (NE de León). Unpublished PhD Thesis, Universidad de Salamanca, Salamanca, Spain.

Corrochano, D., Barba, P., and Colmenero, J.R. 2012. Glacioeustatic cyclicity of a Pennsylvanian carbonate platform in a foreland basin setting: An example from the Bachende Formation of the Cantabrian Zone (NW Spain). Sedimentary Geology, 245-246:76-93.

Cózar, P. and Rodríguez, S. 2003. The palaeoecological distribution of the endothyroids (foraminifera) in the Guadiato area (SW Spain, Mississippian). Palaeogeography, Palaeoclimatology, Palaeoecology, 201(12):1-19.

Cremer, H.G. 1995. Spicule pseudomorphs in Upper Triassic (Norian) chaetetid sponges from the Western Taurids (Antalya-Region, SW Turkey). Geobios, 28(2):163-174.

Cuif, J.P., Feuilée, P., Fischer, J.C., and Pascal, A. 1973. Présence d'astrorhizes chez les Chaetetida mésozoïques. Comptes Rendus de l'Académie des Sciences (series D), 277:2473-2476. 
Della Porta, G., Kenter, J.A.M., and Bahamonde, J.R. 2004. Depositional facies and stratal geometry of an Upper Carboniferous prograding and aggrading highrelief carbonate platform (Cantabrian Mountains, N Spain). Sedimentology, 51(2):267-295.

Della Porta, G., Villa, E., and Kenter, J. 2005. Facies distribution of fusulinida in a Bashkirian-Moscovian (Pennsylvanian) carbonate platform top (Cantabrian Mountains, NW Spain). Journal of Foraminiferal Research, 35(4):344-367.

Dickson, J.A.D., Wood, R.A., and Kirkland, B.L. 1996. Exceptional preservation of the sponge Fissispongia tortacloaca from the Pennsylvanian Holder Formation, New Mexico. Palaios, 11(6):559-570.

Fallon, S.J., McCulloch, M.T., and Guilderson, T.P. 2005. Interpreting environmental signals from the coralline sponge Astrosclera willeyana. Palaeogeography, Palaeoclimatology, Palaeoecology, 228(1-2):58-69.

Fischer, J.C. 1970. Revision et essai de classification des Chaetetida (Cnidaria) post-Paleozoïques. Annales de Paléontologie (Invertébrés), 56(2):151220.

Gallagher, S.J. 1998. Controls on the distribution of calcareous Foraminifera in the Lower Carboniferous of Ireland. Marine Micropaleontology, 34(3-4):187-211.

Gray, D.I. 1980. Spicule pseudomorphs in a new Palaeozoic chaetetid, and its sclerosponge affinities. Palaeontology, 23:803-820.

Hartman, W.D. and Goreau, T.F. 1970. Jamaican coralline sponges: Their morphology, ecology and fossil relatives, p. 205-243. In Fry, W.G. (ed.), The biology of the Porifera. Symposia of the Zoological Society of London, Academic Press, London.

Hartman, W.D. and Goreau, T.F. 1972. Ceratoporella (Porifera: Sclerospongiae) and the chaetetid "corals". Transactions of the Connecticut Academy of Arts and Sciences, 44:138-148.

Hartman, W.D. and Goreau, T.F. 1975. A Pacific tabulate sponge, living representative of a new Order of Sclerosponges. Postilla, 167:1-14.

James, N.P. 1974. Diagenesis of scleractinian corals in the subaerial vadose environment. Journal of Paleontology, 48:785- 799 .

James, N.P. and Choquette, P.W. 1983. Diagenesis 5: Limestones: Introduction. Geoscience Canada, 10:159-161.

Kazmierczak, J. 1979. Sclerosponge nature of chaetetids as evidenced by spiculated Chaetetopsis favrei (Deninger, 1906) from the Barremian of Crimea. Neues Jahrbuch für Geologie und Paläontologie, 2:97-108.

Kershaw, S. 1980. Cavities and cryptic faunas beneath non-reef stromatoporoids. Lethaia, 13(4):327-338.

Kershaw, S. and West, R.R. 1991. Chaetetid growth form and its controlling factors. Lethaia, 24(3):333346.
Kirkland, B.L., Moore, J.C.H., and Dickson, J.A.D. 1993. Well preserved, aragonitic phylloid algae (Eugonophyllum, Udoteaceae) from the Pennsylvanian Holder Formation, Sacramento Mountains, New Mexico. Palaios, 8(1):111-120.

Laghi, G.F., Martinelli, G., and Russo, F. 1984. Localization of minor elements by EDS microanalysis in aragonitic sponges from the St. Cassian Beds, Italian Dolomites. Lethaia, 17(2):133-138.

Machel, H.G, Mason, R.A., Mariano, A.N., and Mucci, A., 1991. Causes and measurements of luminescence in calcite and dolomite, p. 9-25. In Barker, C.E. and Kopp, O.C. (eds.), Luminescence Microscopy and Spectroscopy: Qualitative and Quantitative Applications. SEPM Short Course, 25.

Mastandrea, A. and Russo, F. 1995. Microstructure and Diagenesis of Calcified Demosponges from the Upper Triassic of the Northeastern Dolomites (Italy). Journal of Paleontology, 69(3):416-431.

Merino-Tomé, O., Bahamonde, J., Samankassou, E. and Villa, E. 2009. The influence of terrestrial run off on marine biotic communities: An example from a thrust-top carbonate ramp (Upper Pennsylvanian foreland basin, Picos de Europa, NW Spain). Palaeogeography, Palaeoclimatology, Palaeoecology, 278(1-4):1-23

Millet, J. and Kiessling, W. 2009. First record of coralline demosponges in the Pleistocene: implications for reef ecology. Coral Reefs, 28(4):867-870.

Molineux, A. 1994. A late Pennsylvanian encruster: terminal Paleozoic calcified demosponge?, p. 967-982. In Embry, A.F., Beauchamp, B., and Glass, D.J. (eds.), Pangea: Global Environments and Resources. Canadian Society of Petroleum Geologists Memoir Calgary.

Pérez-Estaún, A., Bastida, F., Alonso, J.L., Marquinez, J., Aller, J., Alvarez-Marron, J., Marcos, A., and Pulgar, J.A. 1988. A thin-skinned tectonics model for an arcuate fold and thrust belt: The Cantabrian Zone (Variscan Ibero-Armorican Arc). Tectonics, 7(3):517537.

Reitner, J. 1987. Euzkadiella erenoensis n. gen. n. sp. ein stromatopore mit spikulärem skelett aus dem oberapt von ereño (prov. Guipuzcoa, Nordspanien) und die systematische stellung der stromatoporen. Paläontologische Zeitschrift, 61(3):203-222.

Reitner, J. and Engeser, T.S. 1987. Skeletal structures and habitats of Recent and fossil Acanthochaetetes (subclass Tetractinomorpha, Demospongiae, Porifera). Coral Reefs, 6:13-18.

Reitner, J. and Neuweiler, F. 1995. Mud mounds: a polygenetic spectrum of fine-grained carbonate buildups. Facies, 32:1-70.

Reitner, J., Wörheide, G., Lange, R., and Schumann-Kindel, G. 2001. Coralline Demosponges - A geobiological portrait. Bulletin of the Tohoku University Museum, 1:210-226. 
Richter, D.K. and Zinkernagel, U. 1981. Zur Anwendung der Kathodolumineszenz in der Karbonatpetrographie. Geologische Rundschau, 70:1276-1302.

Riding, R. 2004. Solenopora is a chaetetid sponge, not an alga. Palaeontology, 47(1):117-122.

Sandberg, P.A. and Hudson, J.D. 1983. Aragonite relic preservation in Jurassic calcite-replaced bivalves. Sedimentology, 30(6):879-892.

Sandberg, P.A., Schneidermann, N., and Wunder, S.J. 1973. Aragonitic ultrastructural relics in calcitereplaced Pleistocene skeletons. Nature, 245:133134.

Sollas, W.J. 1875. Sponges. Encyclopaedia Britannica. Adam and Charles Black, Edinburgh.

Suchy, D.R. and West, R.R. 1988. A Pennsylvanian cryptic community associated with laminar chaetetid colonies. Palaios, 3(4):404-412.

Toomey, D.F. and Winland, H.D. 1973. Rock and biotic facies associated with Middle Pennsylvanian (Desmoinesian) algal buildup, Nena Lucia field, Nolan County, Texas. American Association of Petroleum Geologists Bulletin, 57:1053-1074.

Tucker, M. and Wright, P. 1990. Carbonate Sedimentology. Blackwell Science, London.

Uwe, B. 1981. Mineralogy and chemistry of the lower Pennsylvanian Kendrick fauna, eastern Kentucky: 1. Trace elements. Chemical Geology, 32(1-4):1-16.

Wahlman, G.P. 2002. Upper Carboniferous-Lower Permian (Bashkirian-Kungurian) mounds and reefs, $p$. 271-338. In Kiessling, W., Flügel, E., and Golonka, J. (eds.), Phanerozoic reef patterns. SEPM Special Publication, 72.

West, R.R. 1988. Temporal changes in Carboniferous reef mound communities. Palaios 3:152-169.

West, R.R. 1994. Species in coralline demosponges: Chaetetida. Courier Forschungsinstitut Senckenberg, 172:399-409.
West, R.R. 2011a. Part E, Revised, Volume 4, Chapter 2C: Classification of the fossil and living hypercalcified chaetetid-type porifera (Demospongiae). Treatise Online, 22.

West, R.R. 2011b. Part E, Revised, Volume 4, Chapter 2A: Introduction to the fossil hypercalcified chaetetidtype porifera (Demospongiae). Treatise Online, 20.

West, R.R. 2011c. Part E, Revised, Volume 4, Chapter 2B: Functional morphology of the chaetetid-type porifera. Treatise Online, 21.

West, R.R. 2012a. Part E, Revised, Volume 4, Chapter 2D: Evolution of the hypercalcified chaetetid-type Porifera (Demospongiae). Treatise Online, 35.

West, R.R. 2012b. Part E, Revised, Volume 4, Chapter 2E: Paleoecology of the hypercalcified chaetetid-type Porifera (Demospongiae). Treatise Online, 36.

West, R.R. and Clark, G.R. 1983. Chaetetids, p. 130140. In Broadhead, T.W. (ed.), Sponges and Spongiomorphs: Notes for a Short Course. University of Tennessee, Studies in Geology, 7.

West, R.R. and Kershaw, S. 1991. Chaetetid habitats, p. 445-455. In Reitner, J., and Keupp, H. (eds.), Fossil and Recent Sponges. Springer-Verlag, Berlin.

Wolf, K.H. 1965. Gradational sedimentary products of calcareous algae. Sedimentology, 5(1):1-37.

Wood, R. and Reitner, J. 1988. The Upper Cretaceous "chaetetid" demosponge Stromatoaxinella irregularis n. g. (Michelin) and its systematic implications. Neues Jahrbuch für Geologie und Paläontologie, 177(2):213-224.

Wray, J.L. 1964. Archaeolithophyllum, an abundant calcareous alga in limestones of the Lansing Group (Pennsylvanian), Southeastern Kansas Kansas Geological Survey Bulletin, 170:1-13. 